\title{
Morphological, Ethno biological and Phytopharmacological Attributes of Tridax procumbensLinn. (Asteraceae): A Review
}

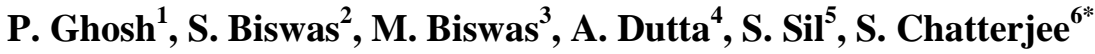 \\ 1, 2, 3, 4, 5, 6 Department of Biotechnology, Techno India University, West Bengal, India \\ EM-4, Salt Lake, Sector- V, Kolkata- 700091, West Bengal, India \\ *Corresponding Author: sirshendu.chatterjee@gmail.com, Tel.: 09734466002
}

Available online at: www.isroset.org

Received: 18/Apr/2019, Accepted: 25/Apr/ 2019, Online: 30/Apr/2019

\begin{abstract}
Tridax procumbens Linn. is an widespread herbaceous weed distributed throughout India. It is commonly known as coat buttons, is also dispensed as Bhringraj, and used as Ayurvedic medicine for liver disorders and hair growth. The plant is an annual or perennial herbaceous weed, found mainly in the croplands, disturbed areas, lawn, and roadsides. Literature survey suggested that the various parts of the plant were reported to possess phytochemical compounds like alkaloids, carotenoids, flavonoids, saponins, fumaric acid, $\beta$-sitosterol, and tannins. It was richly endowed with oleanolic acid, and high content of sodium and potassium are also present. Bioactive components like luteolin, glucoluteolin, quercetin, and isoquercetin also have been reported from its flowers. Primary plant pigments such as chlorophyll and carotenoids also analyzed from leaves. So, it is well known for several potential pharmacological activities like anti-microbial, anti-oxidant, wound healing, insecticidal, hepato-protective, anti-diabetic, immune modulating, anti-cancer, anti-dysentery, anti-inflammatory, and anti-hair fall. The present review study deals with natural habitat, taxonomical, phytochemical, pharmacological and toxicological activities of Tridax procumbens. This study may be helpful for identification and preparation of a clear profile of the plant which may open new avenues in the medical field in the treatment of various diseases.
\end{abstract}

Keywords- Tridax procumbens, Medicinal Weed, Ethnobotany, Morphological, Phytopharmacology.

\section{INTRODUCTION}

Tridax procumbens Linn.,(Figure 1) commonly known as Coat Buttons or Tridax Daisy, belongs to the family of Asteraceae. In West Bengal, it is known as Tridhara or Bishalyakarani [1]. It is a small, semi prostate, annual or perennial and herbaceous creeper weed having short, hairy blade-like leaves. Corolla is yellow color. The stem is elongated to the height of $20-60 \mathrm{~cm}$ tall, branched, sparsely hairy, rooting at nodes. Leaves are simple, opposite, stipulate, lanceolate or ovate. $4-8 \mathrm{~cm}$ long, toothed margin, base wedge-shaped, shortly and petiole, hairy on both surfaces. Flowers are tubular, yellow with hairs, inflorescence capitulum. The plant has two types flower, ray florets and disc florets [2]. The plant is screened for the presence of phytochemical constituents, and anti-oxidant properties $[3,4,5]$ and the results obtained from this investigation have aided in the rationalization of the medicinal use of this plant $[6,7]$.From earlier researches, it was already showed the presence of dexamethasone, luteolin, glucotureolin, $\beta$-sitosterol, flavone, glycoside and quercetin in this plant $[8,9,10]$. The plant has been established for the treatment of wound healing [11], dysentery [12], epilepsy, malaria [13], stomachache, diarrhea, high blood pressure, diabetes [14], hemorrhage and metabolic syndrome [15]. It also possesses insecticidal, anti-septic, parasiticidal and hepato-protective properties and has marked depressant action on respiration [16, 17, 18]. It is a well-known ayurvedic medicine for liver disorders or hepato-protective nature besides gastritis and heartburn [19]. This plant is also used as bioabsorbent for removal of harmful Cr (VI) from the industrial wastewater [20].

Taxonomic Classification

Kingdom Plantae

Subkingdom Tracheobionta

Division Spermatophyta

Subdivision Magnoliophyta 


$\begin{array}{ll}\text { Class } & \text { Magnoliopsida } \\ \text { Subclass } & \text { Asteridae } \\ \text { Order } & \text { Asterales } \\ \text { Family } & \text { Asteraceae } \\ \text { Genus } & \text { Tridax } \\ \text { Species } & \text { procumbens }\end{array}$

Botanical Name: Tridax procumbens Linn.

Synonym

Bengali: Tridhara/Bishalya Karani

Hindi: Khal muriya, Ghamra

Sanskrit: Jayanti Veda

English: Coat buttons, Tridax Daisy, Mexican Daisy

Oriya: Bishalya Karani

Marathi: Gaddi Chemanthi

Tamil: Vettukaya thalai, Thatha

Telugu: Gayapu aku/Palaka aku

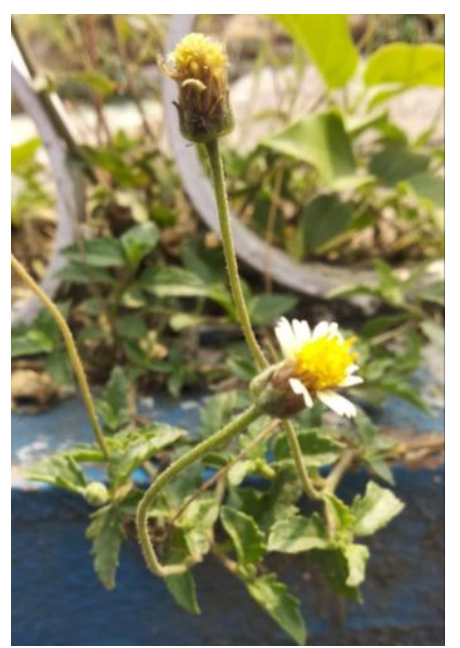

Figure 1: The Plant of Tridax procumbens Linn.

II. BOTANICAL MORPHOLOGY

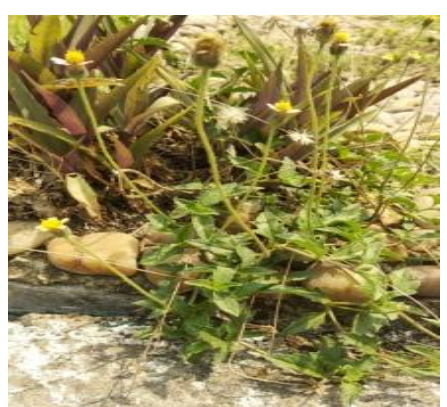

Figure 2: Natural habitat of Tridax procumbens Linn.

Habitat: Tridax procumbens is an annual or perennial herbaceous weed found in tropical and subtropical areas of the world, growing mainly during the rainy season at meadows, croplands, disturbed areas, lawns, roadside (Figure 2) or settled areas. This medicinal herb shows a typical feature of a beneficial weed [21, 22, 23, 24, 25]. 


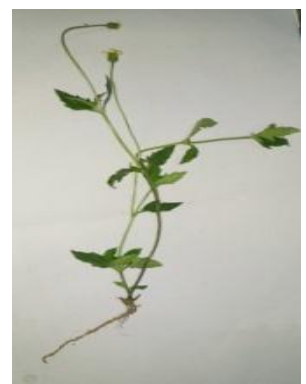

Figure 3: A Complete Plant

Growth: Plants are prostrate or erect (Figure 3), forming patches, with flowering axis 15 to $35 \mathrm{~cm}$ high.

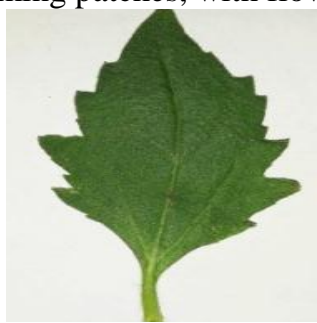

Figure 4: Leaf

Leaves: Leaves are opposite, simple, carried by a petiole, 1 to $2 \mathrm{~cm}$ long. They are thick, soft and dark green. The lamina is oval to lanceolate, 2 to $6 \mathrm{~cm}$ long and 2 to $4 \mathrm{~cm}$ wide, base attenuate in the corner and with strongly and irregularly serrated margin (Figure 4). Both sides are hispid, with tuberculate based bristles. Pubescence is most abundant on the underside.

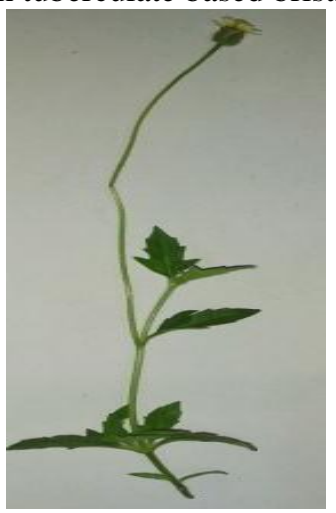

Figure 5: Inflorescences

Inflorescence: Inflorescences in solitary capitulum (Figure 5), held by a peduncle, 12 to $32 \mathrm{~cm}$ long, abundantly hispid. The bracts of the involucre are arranged in 2 rows. They are oval to lanceolate; $6 \mathrm{~mm}$ long, pubescent and green.

Flower: Capitulum formed of 3 to 8 ligulate daisy like female flowers, creamy white on the periphery of capitulum, tridentate (Figure 6). In the center of capitulum, flowers are yellow, tubulate bisexual. The tube, $6 \mathrm{~mm}$ long, with five short tines at the top. This plant has two types of the flower as ray florets and disc florets with basal placentation.

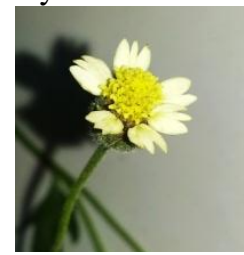

Figure 6: Flower

Fruit:The fruit is a conical achene, $3.5 \mathrm{~mm}$ high, pubescent and brown to black at maturity. It is surrounded by a pappus of feathery bristles, horizontally prostrate at maturity. 


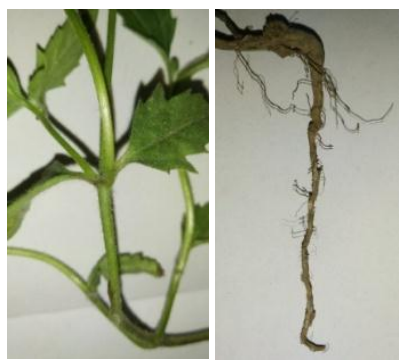

Figure 7: Stem Figure 8: Root

Stem and Root: Stem is cylindrical, hispid, covered with multi-cellular hairs of $1 \mathrm{~mm}$; tuberculation at the base (Figure 7).The root is a strong taproot (Figure 8) system [26].

Genetics: The chromosome numbers of Tridax procumbens has been registered as $2 \mathrm{n}=36$ [27].

\section{TRADITIONAL USES}

Tridax procumbens is a widespread weed and a flowering plant that contains various medicinal values. Traditionally, it has been used in India as anti-coagulant, anti-microbial, insect repellent and as a wound healing agent. It is also used to cure boils, and blisters. This medicinal plant is widely used as a folk medicine like ulcer and hair tonic. Its leaf decoctions were known to treat infectious skin diseases in ethno medicines. It is a well-known ayurvedic medicine for liver disorders because the plant decoctions are acted as hepato-protective in nature. Besides the extracts are also used in gastritis and heartburn [28].It is widely used in wound healing to stop hemorrhage from cuts, bruise, and wounds. The plant is also used to reduce high blood pressure and blood glucose level as well as in dysentery and severe diarrhea [29, 30, 31].

It can be used to prevent falling of hair, and it promotes the growth of hair. The plant is also used in respiratory treatment. It has potent immuno-modulating and insect repellent activity [32].In West Africa and the tropical zone of the world, rural medical practitioners and the tribal peoples use the leaves of the plant as a remedy against conjunctivitis [33]. This medicinal herb was also used in the ethnic system against jaundice and in liver disorders [34]. Ethanol decoctions of Tridax procumbens were also used for curing kidney stone diseases [35].

\section{PHYTOCHEMICAL CONSTITUENTS}

In various research studies, it was showed that the plant has different phytochemical compounds. From the phytochemical screening, it was observed that alkaloids, carotenoids, saponins, flavonoids, and tannins are present in this medicinal plant. The proximate characteristics showed that Tridax procumbens is rich in sodium, potassium, and calcium [36].In an earlier research study, it has been estimated that the leaf of the plant mainly contains crude proteins $26 \%$, crude fiber $17 \%$, soluble carbohydrates $39 \%$, and calcium oxide $5 \%$. On the other hand, luteolin, glucoluteolin, quercetin, and isoquercetin have been reported from its flowers.Fumaric acid, $\beta$-sitosterol also has been reported in the plant [37]. Oleanolic acid which was obtained in reasonable amounts from this plant found to be a potential anti-diabetic agent when tested against alpha-glucosidase [38].

The plant shows different chemical constituents such as 2,6-dihydroxyacetophenone 2-O- $\beta$-D-glucopyranoside, echioidinin, pinostrobin, dihydroechioidinin, tectochrysin 5-glucoside, methyl salicylate glucoside, 5,7,8-trimethoxyflavone, skullcapflavone I 2-methyl ether, androechin, tectochrysin, 5,7,2-trimethoxyflavone, echioidin, skullcapflavone, 5,7dimethoxyflavone, andrographidine [39]. From the aerial parts of Tridax procumbens, a new flavonoid named as procumbenetin has been isolated and characterized by chemical means and spectroscopic techniques [40]. Two new flavones named as 8, 3-dihydroxy-3, 7, 4-trimethoxy-6-O-D-glucopyranosyl and 6, 8, 3-trihydroxy-3, 7, 4-trimethoxy were isolated and characterized based on chemical analysis and spectral methods. Apart from it, four known compounds puerarin, esculetin, oleanolic acid, and betulinic acid were also isolated from the plant parts [41].

A new bisbithiophene named tri-bisbithiophene along with four known terpenoids such as taraxasteryl acetate, $\beta$-amyrenone, lupeol, and oleanolic acids were isolated from the ethyl acetate soluble part of hexane decoctions of this plant [42]. With the help of graded ethanol precipitation followed by mild delignification and size-exclusion chromatography, two water-soluble polysaccharide fractions, WSTP-IA and WSTP-IB were purified from the leaves of Tridax procumbens [43]. 
In a research study, the plant pigments of Tridax procumbens along with some other ethno medicinal plants were estimated. The study showed that total chlorophyll content was $1.424 \mathrm{mg} / \mathrm{g}$ tissue and total carotenoids content was $0.724 \mathrm{mg} / \mathrm{g}$ tissue in this plant. Other two plant pigment research studies observed that these plant pigments content may fluctuate due to the various environmental or other biogeochemical factors like effects of air pollution and it may differ with seasonal changes also [44, 45, 46].

\section{PHARMACOLOGICAL PROPERTY}

Various solvent extracts of Tridax procumbens have been investigated, and it showed different biological activities in animal models and reported to possess anti-oxidant, anti-microbial, wound healing, anti-malarial, anti-cancer, blood coagulation, repellency, anti-inflammatory, hepato-protective, immune-modulatory, anti-diabetic, anti-lithiatic, anti-obesity, antihyperglycemic, analgesic, hemostatic and hypotensive properties. These bioactivities are described as follows.

\section{Anti-oxidant Activity}

The free radicals scavenging activity of the Tridax procumbens fractions and Ascorbic acid was measured in terms of hydrogen donating or radical scavenging ability using the stable free radical 2, 2-diphenyl-1-picrylhydrazyl (DPPH) [47]. The antioxidant activity of the fractions was expressed as $\mathrm{IC}_{50}$ which was defined as the concentration $(\mathrm{mg} / \mathrm{ml})$ of methanol extract fractions that indicates the formation of DPPH radicals by $50 \%$ [48].

\section{Anti-bacterial Activity}

In an earlier research study, it has reported that the whole plant parts of Tridax procumbens have anti-microbial activity on various species of bacteria. An entire plant is squeezed between the palms of hands to obtain juice which is applied twice a day for 4-5 days to cure cuts and wounds. The extract of the whole plant showed anti-microbial property only against Pseudomonas aeruginosa with the help of disk diffusion assay. Four strains of bacteria employed in a test among them two were grampositive Bacillus subtilis, Staphylococcus aureus and two were gram-negative Escherichia coli and Pseudomonas aeruginosa [49]. Only ethanol extract was prominently showed this activity only against Pseudomonas aeruginosa strains. Multidrugresistant nosocomial strains of Pseudomonas isolated from ventilator-associated pneumonia, urinary tract infection as well as bloodstream infection showed significant sensitivity to extracts. This study showed the efficacy of Tridax procumbens as an anti-pseudomonal agent as well as a source of formulations for the treatment of nosocomial infections caused by Pseudomonas aeruginosa [50].

\section{Wound Healing Activity}

Wound healing activity of the plant decoction involves a complex interaction between epidermal and dermal cells, the extracellular matrix, controlled angiogenesis, and plasma-derived proteins all coordinated by cytokines and growth factors [51]. Waterleaf decoctions were also effectively increasing lysyl oxidase but to a lesser degree than whole plant decoctions. It has been observed that the extract of leaves of this plant promotes wound healing in both healthy and immune-compromised rats. The plant can increase lysyl oxidase as well as protein and nucleic acid content in the granulation tissue, as a result of the increase in glycosaminoglycan content [52].

\section{Anti-fungal Activity}

In a research study, disc diffusion method was performed against two fungal strains namely, Aspergillus flavus and Aspergillus niger to determine the antifungal activity of the plant decoctions.Total activity was observed by minimum inhibitory concentrations and by minimum fungicidal concentrations. The flavonoidsdecoction showed the highest activity against Aspergillus niger, but alkaloids decoction showed no activity against both the test fungi [53].

\section{Anti-malarial Activity}

The water and ethanol decoctions have anti-plasmodial properties against chloroquine-resistant Plasmodium falciparum. The decoctions have low toxicities to human RBCs though further animal toxicity studies need to be carried out on the plant [54].

\footnotetext{
Anti-cancer Activity

The plant-derived compounds were used to observe the cytotoxicity against human lung cancer cell line by MTT assay. The compound showed $90 \%$ reduced cell viability. The result of NMR, MS and IR spectra revealed that the compound is Lupeol. The anti-cancer potential of the Lupeol against human lung cancer cell line has been evaluated by clonogenic survival determination, cell cycle control, Cell-based assay for inhibition of COX-2 activity and DNA fragmentation. The analysis showed that $320 \mu \mathrm{g} / \mathrm{ml}$ concentration of Lupeol compound exhibited significant anti-cancer activity [55].
} 


\section{Blood Coagulation and Haemostatic Activity}

Water decoctions of leaves showed significant blood coagulation activity, and for that reasons, it may be used as a potent haemostatic agent [56]. The haemostatic property of the leaves of the plant of the various solvent extracts was determined in vitro by employing Lee-White's method as the ethanol extract reduces the clotting time in the blood samples of all the experiments [57].

\section{Repellency Activity}

In a research study, essential oils were extracted by steam distillation process from leaves and investigated for its local repellency activities against malaria parasite Anopheles stephensi in mosquito cages [58,59]. All essential oils were tested at three various concentrations. The essential oils of the plant exhibited noticeable repellency effect [60].

\section{Anti-inflammatory Activity}

Tridax procumbens have significant anti-inflammatory properties. The anti-inflammatory action of the plant decoction may be due to corticotrophic influence as evident from the increase in weight [61].The active fraction of the plant was ethyl acetate fraction and was found to contain moderate polar natural compounds: alkaloids and flavonoids. These bioactive compounds have applied in counteracting reactive oxidative species indicated the pathogenesis of inflammation and related ailments [62].

\section{Hepato-protective Activity}

The hepato-protective property of leaves showed significant protection in the alleviation of DGalactosamine/Lipopolysaccharide-induced hepato-cellular injury. Both the compounds have been proposed to be hepato-toxic due to its ability to damage liver cells. The multifocal necrosis produced by D-Galactosamine and the lesion of viral hepatitis in humans is similar. This amino sugar bloc the transcription process and indirectly hepatic protein synthesis and as a consequence of toxicity; it causes hepatitis within $8 \mathrm{hr}$ after administration [63].

\section{Immuno-modulatory Activity}

Ethanol decoctions of leaves of the plant have shown an immune-modulatory effect in an animal model [64]. Stimulation of immune response was also observed along with an elevation in haemo-agglutination antibody [65].

\section{Anti-diabetic Activity}

Water and alcoholic decoctions of leaves showed a significant decrease in the blood glucose level in the animal model. The oral administration of acute and sub-chronic doses of 50\% methanol decoctions significantly reduces fasting blood glucose levels in diabetic rats [66].The plant extracts have been widely used in various herbal drugs and is also reported to possess the activities of lowering blood glucose levels. The oral administration of water, alcoholic and petroleum ether decoctions of the leaves on animals at a dose level of $200 \mathrm{mg} / \mathrm{kg}$ of body weight orally administered for seven days. Among these water and alcoholic decoctions significantly reduces the blood glucose level in the animal model and petroleum ether extract exhibits a feeble anti-diabetic effect [67].

\section{Anti-lithiatic Activity}

Ethanol extract of the plant was also used for treating kidney stone disorders. It showed activity against $0.75 \% \mathrm{v} / \mathrm{v}$ ethylene glycol and 2\% w/v ammonium chloride induced calcium oxalate urolithiasis, and hyperoxaluria induced oxidative stress in animal models. Treatment with the decoctions of the plant was able to reduce calculogenesis induced urinary excretion and renal deposition of calcium oxalate and resultant lipid peroxidation, indicating anti-urolithiasis and anti-oxidant effects [68, 69].

\section{Anti-obesity Activity}

In a research investigation, the animal receiving treatment with the plant decoctions showed a significant reduction in total cholesterol, triglycerides, total protein, free fatty acids and elevation of high-density lipoprotein cholesterol levels [70].

\section{Analgesic Activity}

Lyophilized decoctions of the plant were found to be potential analgesic [71].

\section{Hypotensive Activity}

The cardiovascular effect was obtained from the water decoctions of leaves were investigated on anesthetized animals. The water decoctions can cause significant dose-dependent decreases in the mean arterial blood pressure. The higher dose leads to a significant reduction in heart rate whereas lower dose did not cause any changes in the same [72]. 


\section{Toxicity Studies}

From various research studies, the decoctions of Tridax procumbens were reported to have different pharmacological effects. The acute toxicity study was done by using the method of Lorkes [73]. The result of acute toxicity was based on intraperitoneal administration where the compound in the decoctions was directly transported through the blood and circulated to the target organ to exhibit their toxicity. The administration to the test animal was oral, and the $\mathrm{LD}_{50}$ may be much higher since the decoctions will undergo metabolism to produce a new product which could be less toxic. After acute administration, signs of toxicity observed including salivation, nose, and mouth on the floor of the cage and restlessness. The $\mathrm{LD}_{50}$ of the decoctions was $2100 \mathrm{mg} / \mathrm{kg}$ body weight, and all the survived animals gained body weight and organ ratio as compared to the untreated control [74].

Results from short term toxicity studies of the crude ethyl acetate decoctions of the plant were concluded that the liver of test animals was significantly affected at all the dose levels. There was a significant increase in ALT and decrease in AST effects [75].The reduction in the serum AST activity following administration of the decoctions may be attributed to the reduced rate of synthesis in the liver. The rise in the ALT activity may imply that the administration of the decoction has resulted in hepatocellular destruction that leads to the leakage of these enzymes into circulation. The administration of the decoction did not produce a significant increase in ALP activity. In histopathology, there was old hemorrhage indicated by haemosiderin deposition throughout the entire liver and kidney tissues [76].

\section{CONCLUSION}

Tridax procumbens Linn. has enormous potential for botanical, phytochemical, nutritional and pharmacological properties. From the above review study and explanation, it is observed that the plant has been extensively used in the ancient system of medicine for various biological disorders and it possess various prominent phytopharmacological activities, as it is briefly discussed in the review article. There is vast scope for research in the direction of more pharmacological activities of this plant and to elucidate the mechanism of action of the same in the future. This medicinal plant can be a vital source of herbal drugs for the pharmaceutical industry in the future as well $[77,78]$.

\section{Acknowledgment}

The authors are grateful to Dr. Srabani Karmakar, Assistant Professor, Department of Biotechnology, Techno India University, and West Bengal for continuous help to do the review study. The authors are obliged to Dr. Madhusudan Mondal, Former Additional Director, Botanical Survey of India, and Kolkata for identification of the plant and taxonomical inputs. The authors are also thankful to Labani Hazra and Sudip Kumar Nag, M.Sc Final year student, Department of Biotechnology, Techno India University, West Bengal, and India.

\section{Conflict of Interest}

The author declares no conflict of interest.

\section{REFERENCES}

[1]. A.H.M.M. Rahman, M.S. Alam, S.K. Khan, Ferdous Ahmed, A.K.M. Rafiul Islam, M.M Rahman, "Taxonomic Studies on the Family Asteraceae (Compositae) of the Rajshahi Division”, Research Journal of Agriculture and Biological Sciences, Vol. 4, Issue. 2, pp. 134-140, 2008.

[2]. P. Meena, K. Kaushal, R. Mishra, "Tridax Procumbens: Pharmacological Activities-A Review Article”, International Ayurvedic Medical Journal, Vol. 4, Issue. 11, pp. 3392-96, 2016

[3]. R. Elsaveth, G. Yenkateshwarulu, M. sabat, V. Harikrishna, CH. Jyoti, K. Lath, "Phytochemical screening and analytical studies of Tridax parviflora", Universal journal of pharmacy, Vol. 2, Issue. 3, pp. 144-147, 2013.

[4]. EK. Elumalai, M. Ramachandran, T. Thirumalai, P. Vinothkumar, "Antibacterial activity of various leaf extracts of Merremiae marginata", Asian Pacific Journal of Tropical Biomedicine, Vol. 1, Issue. 5, pp. 406-408, 2011.

[5]. MA. Kale, SR. Shahi, VG. Somani, PB. Shamkuwar, AS. Dhake, "Hemostatic activity of leave of a Tridax procumbens Linn." International Journal of Green Pharmacy, Vol. 2, Issue. 1, pp. 54-55, 2008.

[6]. OAniel Kumar, LMNaidu, “Antibacterial potential of Tridax procumbens L. against human pathogens", International Journal of Pharmaceutical Sciences, Vol. 2, Issue. 2, pp. 21-30, 2011.

[7]. DAbba, HIInabo, SEYakubu, OSOlonitola, "Phytochemical analysis and antibacterial activity of some powdered herbal preparations marketed in kaduna metropolis", Science World Journal,Vol. 4, Issue. 1, pp. 23-26, 2009.

[8]. RN Yadawa, K Saurabh, "A new flavone glycoside: 5, 7, 4-Trihydraxy- 6, 3-dimethasey Falavone 5-0 alpha-L-rhamnopyramoside from the leaves of Tridax procumbens Linn.”, J AsianNat Prod Res,Vol. 1, Issue. 2, pp. 147-52, 1998.

[9]. M. Ali, E. Rawinder, R. Ramchandran, “A new flavonoid from the aerial parts of Tridax procumbens”, Fitoterapia, Vol. 72, Issue. 3, pp. 313-5, 2001.

[10]. MS. Ali, M Jahangir, “A bis-bithiophene from Tridax procumbens L. (Asteraceae)”, Nat Prod Lett, Vol. 16, Issue. 4, pp. 217-21, 2002.

[11]. A. Taddei, A. J. Rosas Romero, “Bioactivity studies of extracts from Tridax procumbens”, Phytomedicine, Vol. 7, Issue. 3, pp. 235-8, 2000. 
[12]. S. Mundada, R.Shivhare, "Pharmacology of Tridax procumbens a weed: review”, International Journal of Pharm Tech Research, Vol. 2, Issue. 2, pp. 1391-94, 2010.

[13]. S. Rajkumar, A.Jebanesan, "Repellent activity of selected plant essential oils against the malarial fever mosquito, Anopheles stephensi", Tropical Biomedicine, Vol. 24, Issue. 2, pp. 71-5, 2007.

[14]. J. Pande, H. Padalia, S. Donga, S. Chanda, "Pharmacognostic, physicochemical and phytochemical studies of Andrographis echioidesNees. And Tridax procumbens L. leaf and stem", The Pharma Innovation Journal, Vol. 7, Issue. 6, pp. 303-15, 2018.

[15]. L. Suseela, A. Sarasvathy, P.Brindha, "Pharmacognostic studies on Tridax procumbens L.(Asteraceae)”, Journal of Phytological Research, Vol. 5, Issue. 2, pp. 141-47, 2002.

[16]. OV. Njoku, C. Obi, "Phytochemical constituents of some selected medicinal Plants", African Journal of Pure and Applied Chemistry,Vol. 3, Issue. 11, pp. 228-233, 2009.

[17]. K. Hegde, AB. Joshi, "Preliminary Phytochemical Screening and Antipyretic Activity of Carissa Spinarum Root Extract", Scholars Research Library Der Pharmacia letter,Vol. 2, Issue. 3, pp. 255, 2010.

[18]. HM. Salahdeeen, BA.Murtala, "Vasorelaxant effects of aqueous leaf extract of Tridax procumbens on aortic smooth muscle isolated from the rat”, Journal of smooth muscle and research, Vol. 48, Issue. 2, pp. 37-45, 2012.

[19]. DS. Wani, AA. Sogi,Wani, BS. Gill, US. Shivhare, "Physico-chemical properties of starches from Indian kidney bean (Phaseolus vulgaris) cultivar", Int J Food Sci Technol.Vol. 52, Issue. 7, pp. 4078-89, 2015.

[20]. S. Malairajan, AA. Mengistie, VS. Rajamanickam, "Studies on the removal of hexavalent chromium from industrial wastewater by using biomaterials", Electronic Journal of Environmental, Agricultural and Food Chemistry, Vol. 6, Issue. 11, pp. 2557-64, 2007.

[21]. D.A. Bhagwat, S.G. Killedar, R.S. Adnaik, "Anti- diabetic activity of leaf extract of Tridax procumbens", Intnl. J. Green Pharma,Vol. 2, Issue. 2, pp. 126-28, 2008.

[22]. P. Ghosh, P. Das, C. Das, S. Mahapatra, S.Chatterjee, "Morphological Characteristics and Phyto-pharmacological detailing of Hatishur (Heliotropium indicum Linn.): A Concise Review". Journal of Pharmacognosy and Phytochemistry. Vol. 7, Issue. 5, pp. 1900-07, 2018.

[23]. P. Ghosh, C. Ghosh, S. Das, C. Das, S. Mandal\&S. Chatterjee, "Botanical Description, Phytochemical Constituents and Pharmacological Properties of Euphorbia hirta Linn.: A Review”, International Journal of Health Sciences and Research, Vol. 9, Issue. 3, pp. 273-86, 2019.

[24]. P. Ghosh, S. Chatterjee, P. Das, S. Karmakar, S. Mahapatra, "Natural Habitat, Phytochemistry and Pharmacological Properties of a Medicinal Weed - Cleome Rutidosperma DC. (Cleomaceae): A Comprehensive Review", International Journal of Pharmaceutical Sciences and Research, Vol. 10, Issue. 4, pp. 1605-12, 2019.

[25]. S. Das, N.Mondal, S. Mondal, P. Ghosh, C. Ghosh, C. Das, S. Chatterjee. "Botanical Features, Phytochemical and Pharmacological Overviews of Oldenlandia corymbosa Linn.: A Brief Review”, The Pharma Innovation Journal, Vol. 8, Issue. 2, pp. 464-68, 2019.

[26]. S. Kumar, A. Prasad, S.V. Iyer, S. Vaidya, "Pharmacognostical, Phytochemical and Pharmacological Review on Tridax procumbens Linn", International Journal of Pharmaceutical \& Biological Archives, Vol. 3, Issue. 4, pp. 747-51, 2012.

[27]. ZY. Xie, CM. Zheng, "Cytological studies on 13 species of Compositae from Hainan, China”, Acta Phytotaxonomica Sinica, Vol. 41, Issue. 6 , pp. 545-52, 2003.

[28]. A. Jayashree, M. Sivaprakasam, "Studies on the antibacterial activity of the extracts from Tridax procumbens L and Ixora coccinea L", Biomedicine,Vol. 28, Issue. 3, pp. 190-94, 2008.

[29]. G. Babu, Sanjeeva, K. L. Bairy, “Effect of Tridaxprocumbens on burn wound healing”, Indian Drugs, Vol. 40, Issue. 8, pp. 488-91, 2003.

[30]. P.V.Diwan, L.D.Tilloo, D.Kulkarni, "Influence of Tridax procumbens on wound healing”, Indian J. Med Res, Vol. 75, pp. 450-54, 1982.

[31]. Gaikwadi, Vadlamudi, V.P. Waghmaee, S.P. Maral, V.J. Ranteke, V.D. Dhok, "Phytochemical analysis of aqueous extract of few medicinal plants", Journal of Ethnopharmacology, Vol. 2, pp. 91-92, 2003.

[32]. S. Mundada, R. Shivhare, "Pharmacology of Tridax procumbens", International Journal of Green Pharmacy, Vol. 5, pp. 91-94, 2008.

[33]. A. Jain and A. Jain, "Tridax procumbens $(L)$ : A weed with Immense Medicinal Importance: A Review", International Journal of Pharma and BioSciences, Vol. 3, Issue. 1, pp. 544-52, 2012.

[34]. S.L. Udupa, A.L. Udupa, DR. Kulkarni, “India Plantamedica”, Indian Journal of Pharmaceutical Sciences, Vol. 57, pp. 325-27, 1991.

[35]. B. Sailaja, K. Bharathi, K.V.S.R.G. Prasad, "Protective effect of Tridax procumbens L. on Calcium Oxalate Urolithiasis and oxidative stress", An International Journal of Advances in Pharmaceutical Sciences, Vol. 2, pp. 9-14, 2011.

[36]. C. Ikewuchi Jude, C. Ikewuchi Catherine, M. IgbohNgozi, “Chemical Profile of Tridax procumbens Linn.” Pakistan Journal of Nutrition, Vol. 8, Issue. 5, pp. 548-50, 2009.

[37]. R.K. Verma, M.M. Gupta, "Lipid constituents of Tridax procumbens", Phytochemistry, Vol. 27, Issue. 2, pp. 459-63, 1988.

[38]. Md. S. Ali, Md. Jahangir, S.S. Hussan, Md.I. Choudhary, "Inhibition of alpha-glucosidase by oleanolic acid and its synthetic derivatives", Phytochemistry, Vol. 60, pp. 295-99, 2002.

[39]. J. Anjaria, M. Parabia, S. Dwivedi, “Ethnovet Heritage-Indian Ethnoveterinary Medicine an Overview”, Pathik Enterprise, Ahmedabad, India, 2002.

[40]. M. Ali, E. Ravinder, R.Ramachandran, "A new extract of Borassus flabellifer L. male flowers (inflorescences) flavoanoid from the aerial parts of Tridax procumbens. In experimental animals", Fitoterapia, Vol. 72, Issue. 3, pp. 313-15, 2001.

[41]. X. Runsheng, Z. Jing, Y. Ke, “Two New Flavones from Tridax procumbens Linn.”, Molecules, Basel Switzerland, Vol. 15, Issue. 9, pp. 6357. 64, 2010.

[42]. Md. S. Ali, Md. Jahangir, “A Bis-Bithiophene from Tridax Procumbens L. (Asteraceae)”, Natural Product Letters, Vol. 16, Issue. 4, pp. 217-21, 2002.

[43]. T. ShanthaRaju, E.A. Davidson, "Structural features of water-soluble novel polysaccharide components from the leaves of Tridax procumbens Linn.”, Vol. 258, pp. 243-54, 1994.

[44]. P. Ghosh, P. Das, R. Mukherjee, S. Banik, S. Karmakar, S. Chatterjee, "Extraction and Quantification of Pigments from Indian Traditional Medicinal Plants: A Comparative Study between Tree, Shrub, and Herb”, International Journal of Pharmaceutical Sciences and Research. Vol. 9, Issue. 7, pp. 3052-59, 2018.

[45]. S. Mukherjee, S. Chowdhury, P. Ghosh, S. Chatterjee, M. Bhattacharya, "Air Pollution has Deep Impact on Plant Pigments: A Comparative Study on Differentially Polluted Areas of West Bengal”, Pollution Research, Vol. 37, Issue. 3, pp. 690-93, 2018. 
[46]. S. Banik, R. Mukherjee, P. Ghosh, S. Karmakar, S. Chatterjee, "Estimation of Plant Pigments Concentration from Tulsi (Ocimum sanctum Linn.): A Six Months Study”, Journal of Pharmacognosy and Phytochemistry, Vol. 7, Issue. 4, pp. 2681-84, 2018.

[47]. A. Taddei, A.J. Rosas-Romero, "Bioactivity studies of extracts from Tridax procumbens", Phytomedicine, Vol. 7, Issue. 3, pp. 235-38, 2000.

[48]. R. Chandar; A.K. Khanna, R. Kanwal, A.K. Rastogi, “Antioxidant and lipid lowering activities of Indian Black Tea”, Ind. J. Clinical Biochem., Vol. 20, Issue. 1, pp. 153-59, 2005.

[49]. R.B. Mahato, R.P. Chaudhary, "Ethnomedicinal study and antibacterial activities of selected plants of Palpa district", Nepal. Scientific World,Vol. 3, Issue. 3, pp. 26-31, 2005.

[50]. C. Pai, U. Kulkarni, M. Borde, S. Murali, P. Mrudula, Y. Deshmukh, "Antibacterial Activity of Trida xprocumbens with Special Reference to Nosocomial Pathogens”, British Journal of Pharmaceutical Research, Vol. 1, Issue. 4, pp. 164-73, 2011.

[51]. R. Nia, D.H. Paper, E.E. Essien, O.H. Oladimeji, K.C. Iyadi and G. Franz, "Investigation into in-vitro radical scavaging and in-vivo antiinflammatory potential of Tridax procumbens", Nigerian journal of physiological science,Vol. 18, Issue. 1, pp. 39-43, 2003.

[52]. R. S. Bhat, J. Shankrappa, H. G. Shivakumar, "Formulation and evaluation of polyherbal wound treatments", Asian Journal of Pharmaceutical Sciences, Vol. 2, Issue. 1, pp. 11-17, 2007.

[53]. A. Jindal, P. Kumar, "In Vitro Antifungal Potential of Tridax Procumbens L. against Aspergillus Flavus and Aspergillus Niger", Asian Journal of Pharmaceutical and Clinical Research, Vol. 6, Issue. 2, pp. 123-25, 2013.

[54]. R.A. Opong, A.K. Nyarko, D. Dodoo, F.N. Gyang, K.A. Koram, N.K. Ayisi, “Antiplasmodial Activity of Extracts of Tridax Procumbens and Phyllanthus Amarus in In Vitro Plasmodium Falciparum Culture Systems", Ghana Medical Journal, Vol. 45, Issue. 4, pp. 143-50, 2011.

[55]. S. Sankaranarayanan, P. Bama, S. Sathyabama, N. Bhuvaneswari, "Anticancer Compound Isolated From The Leaves of Tridax Procumbens Against Human Lung Cancer Cell A-549”, Asian Journal of Pharmaceutical and Clinical Research, Vol. 6, Issue. 2, pp. 91-96, 2013.

[56]. S.B. Jhample, S.B. Gajdhane, P.J. Kasabe, P.K. Bhagwat, P.B. Dandge, "Phytochemical screening and in vitro antimicrobial activity of Tridax procumbens L.”, Research Journal of Life Sciences, Bioinformatics, Pharmaceutical and Chemical Sciences, Vol. 1, Issue. 1, pp. 44-53, 2015.

[57].P.B. Godkar, "Textbook of Medical Laboratory Technology”, Edition 3, Bhalani Publishing House, Mumbai, pp. 477-490, 1994.

[58]. H. Pareek, S. Sharma, B.S.Khajja, K. Jain, G.C.Jain, "Evaluation of hypoglycemic and anti-huperglycemic potential of Tridax procumbens (Linn.)”, BMC Complementary and Alternative Medicine, Vol. 9, Article No. 48, 2009.

[59]. S. Chanda, K. Rakholiya, K. Dholakia, Y. Baravalia, "Antimicrobial, antioxidant, and synergistic properties of two nutraceutical plants: Terminalia catappa L. and Colocasia esculenta L.”, Turkish Journal of Biology, Vol. 37, pp. 81-91, 2013.

[60]. S.Rajkumar, A. Jebanesan, "Repellent activity of selected plant essential oils against the malarial fever mosquito Anopheles stephensi.",Tropical Biomedicine,Vol. 24, Issue. 2, pp. 71-75, 2007.

[61]. P.V.Diwan, I.Karwande, I.Margaret, P.B.Sattur, "Pharmacology and biochemical evaluation of Tridax procumbens", Journal of Pharmacology,Vol. 5, pp. 200-207, 1989

[62]. V. Prabhu, Vinoth, G. Nalini, N. Chidambaranathan, S. Kisan, Sudarshan, "Evaluation of anti-inflammatory and analgesic activity of Tridax procumbens Linn. against formalin, acetic acid and CFA induced pain models", International Journal of Pharmacy and Pharmaceutical Sciences, Vol. 3, pp. 126-30, 2011.

[63]. R. Vilwanathan, K. S. Shivashangari, T. Devak, "Hepatoprotective activity of Tridax procumbens against d-galactosamine/lipopolysaccharideinduced hepatitis in rats", Journal of Ethnopharmacology,Vol. 101, pp. 55-60, 2005.

[64]. M.K. Oladunmoye, "Immunostimulatory Activity of Ethanolic Leaf Extract from Ocimum gratissimum in Albino Rat Orogastrically Dosed with Escherichia coli (NCIB 86)”, Journal of Pharmacology and Toxicology, Vol. 1, Issue. 4, pp. 389-94, 2006.

[65]. U. Tiwari, B. Rastogi, P. Singh, D.K. Saraf, S.P. Vyas, "Immunomodulatory effects of aqueous extract of Tridax procumbens in experimental animals", Journal of Ethanopharmacology,Vol. 92, Issue. 1, pp. 113-19, 2004.

[66]. D.A. Bhagwat, S.G. Killedar, R.S. Adnaik, “Antidiabetic activity of leaf extract of Tridax procumbens”, Inn. Journal of Green Pharma.,Vol. 2, pp. 126-28, 2008.

[67]. A. Saini, H. K. Soni, P. Gupta, “A Review on Tridax Procumbens”, Imperial Journal of Interdisciplinary Research, Vol. 2, Issue. 8, pp. 308-319, 2016.

[68]. R.S. Bhat, J. Shankrappa, H.G. Shivakumar, "Formulation and evaluation of polyherbal wound treatments", Asian Journal of Pharmaceutical Sciences, Vol. 2, pp.11-17, 2007.

[69]. M. Niharika, J. Himabindu, K. Ramanjaneyulu, "Evaluation of in vitro antiurolithiatic activity of Tridax procumbens", International Journal of Scientific Research, Vol. 7, Issue. 1, pp. 405-406, 2018.

[70]. V. Bharathi, Kalavathi, A. Shanmugapriya, S. JannathulFirdous, "Anti-obesity effect of Tridax procumbens in atherogenic diet-induced obese rats", IJPT, Vol. 3, Issue. 1, pp. 1565-69, 2011.

[71]. A. S. Deshmukh, P. G. Morankar, M. R. Kumbhare, "Review on Analgesic Activity and Determination Methods", Pharmtechmedica, Vol. 3, Issue. 1, pp. 425-28, 2014.

[72]. O. Koukoui, L. Michodjehoun, I. Hoteyi, A. Sezan, "Hypotensive Activity of Tridax Procubens hydro ethanolic extract: Roles of transport of sodium and potassium in Rat Wistar", American Journal of Pharmtech Research, Vol. 8, Issue. 1, pp. 1-14, 2018.

[73]. D. Lorke, “A new Approach to Practical Acute Toxicity testing”, Archives of Toxicoloogy, Vol. 54, Issue. 4, pp. $275-87,1983$.

[74]. P. J. Wright, D. T. Plummer, "The use of urinary enzyme measurement to detect renal damages caused by nephrotoxic compounds", Biochem. Pharmacol. Vol. 23, Issue. 1, pp. 65-73, 1974.

[75]. P. V. Diwan, I. Karwande, I. Margaret, P. B. Sattar, "Pharmacology and biochemical evaluation of Tridax procumbers on inflammation", Indian journal of pharmacology, Vol. 21, pp. 1-7, 1989.

[76]. G. Zbinden, M. Flury-Roversi, "Significance of the LD50 test for the toxicological evaluation of chemical substances", Arch Toxicol, Vol. 47, Issue. 2, pp. 77-99, 1981.

[77]. A. Dutta, S. Biswas, M. Biswas, P. Ghosh, C. Ghosh, S. Das, S. Chatterjee. "Phytochemical Screening, Anti-oxidant and Anti-microbial Activity of Leaf, Stem and Flower of Rangoon Creeper: A Comparative Study.” Journal of Medicinal Plants Studies, Vol. 7 Issue. 2, pp. $123-130,2019$.

[78]. B. Sharma and M. Bhat, "Ethnobiology, Phytochemistry and Pharmacology of Usnea Longissima: A Review", International Journal of Scientific Research in Biological Sciences, Vol. 6, Issue. 1, pp. 263-69, 2019. 


\section{AUTHOR'S PROFILE}

Pranabesh Ghosh pursued B.Sc in Life Sciences and M.Sc in Environmental Sciences from Visva Bharati University, India. He also did Post Graduation in Business Management from International School of Business, India. $\mathrm{He}$ also pursued a certificate course in Science Journalism. $\mathrm{He}$ is pursuing $\mathrm{PhD}$ in Biotechnology from Department of Biotechnology, Techno India University, West Bengal, and India. He is also working as Teaching Assistant in the same department since January 2017. He has published several Papers in UGC approved, peer-reviewed, and reputed journals. He has attended and presented papers at various conferences and symposiums. His area of research work includes Pharmaceutical and Environmental Biotechnology, Ethnobotany, Nanobiotechnology etc. He has 5 years of teaching and research experiences.

Swagata Biswas is pursuing M.Sc. in Biotechnology from Techno IndiaUniversity, West Bengal, India. She has completed B. Tech in Biotechnology from Maulana Abul Kalam Azad University of Technology (formerly known as WBUT). She has training experiences in plant tissue culture and food industries. She has attended and presented poster in several International and State level symposium and conferences. She has also published a research article in peer- reviewed and referred journal.

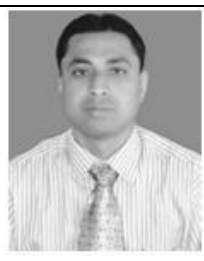

Maitrayee Biswas is pursuing M.Sc. in Biotechnology from Techno India University, West Bengal, India. She has completed B.Sc in Microbiology $(\mathrm{H})$ from Calcutta University (Dinabandhu Andrews College). She has attended a plant tissue culture workshop. She has also attended and presented poster in several State and International level symposium and conferences. She has also published a research article in peer- reviewed and indexed journal.

Alolika Dutta is pursuing M.Sc. in Biotechnology from Techno India University, West Bengal, India. She has completed B. Sc in Biotechnology (H) from the University of Burdwan (BIMS). She has attended a plant tissue culture workshop in Sristi AgroBiotech. She has also presented poster in several symposium and conferences. She has also published a research article in peer- reviewed and reputed journal.

Sayantan Sil is pursuing M.Sc. in Biotechnology from Techno India University, West Bengal, India. He has completed B.Sc in Zoology from Chakdaha College (University of Kalyani). He has attended several National and International Level Conferences and workshop. He has also presented poster in International Young Researcher Meet on Advanced Techniques in Biotechnology.

Dr. Sirshendu Chatterjee did his PhD from Calcutta School of Tropical Medicine on 2011. He is currently working as Assistant Professor in Department of Biotechnology, Techno India University, and West Bengal since November, 2015. His main area of research is Natural Medicine, Analytical Biochemistry, Homology Modeling, and Nanotechnology. He has published more than 30 research papers in peer reviewed journal.

\section{Contribution of Different Authors:}

Pranabesh Ghosh: Article Planning, Literature Survey, Final Manuscript Preparation

Swagata Biswas: Manuscript Drafting

Maitrayee Biswas: Referencing of Article

Alolika Dutta: Proofing Reading and Editing

Sayantan Sil: Photography and Figure Labeling

Sirshendu Chatterjee: Manuscript Editing (Plagiarism Checking and correction, Grammatical Error Corrections) and Correspondence for Publications 